\title{
Toxicity of profenofos to the springtail, Folsomia candida, and ammonia-oxidizers in two agricultural soils
}

\author{
Yu-Rong Liu $\cdot$ Yuan-Ming Zheng $\cdot$ Ji-Zheng He
}

Accepted: 7 February 2012/Published online: 24 February 2012

(C) Springer Science+Business Media, LLC 2012

\begin{abstract}
Extensive use of organophosphorus insecticide profenofos (PFF) for agricultural and house-hold purposes has led to serious environmental pollution, with potential risk to organisms in the ecosystem. This study examined the toxicity of PFF to the soil springtail Folsomia candida and ammonia-oxidizers through a series of toxicity tests conducted on two agricultural soils. It was found that the survival, reproduction, hsp70 gene expression of $F$. candida and the soil potential nitrification rate (PNR) were sensitive to the PFF, whereas no apparent change was observed in the abundance of ammonia-oxidizers. The reproduction of $F$. candida was the most sensitive endpoint (mean $0.10 \mathrm{mg} / \mathrm{kg}$ of $\mathrm{EC}_{50}$ value) for PFF, although the test was more time-consuming. The results of the acute toxicity tests suggested that the survival of $F$. candida could be considered as the most suitable bioindicator for fast screening of PFF toxicity because of its fast and easy test procedure. In addition, the hsp70 gene expression in $F$. candida and the PNR could be used as important parameters for assessment of PFF toxicity. The threshold concentration based on the obtained endpoints differed in the two soils, and consequently the soil property should be considered in toxicity assessments of contaminated soils.
\end{abstract}

Keywords Organophosphorus pesticide - Toxicity · Folsomia candida $\cdot$ Nitrifying activity $\cdot$ Hsp70 gene

Y.-R. Liu · Y.-M. Zheng · J.-Z. He ( $\square)$

State Key Laboratory of Urban and Regional Ecology, Research Center for Eco-Environmental Sciences, Chinese Academy of Sciences, 18 Shuangqing Road, Beijing 100085, China e-mail: jzhe@ rcees.ac.cn

\section{Introduction}

Profenofos (PFF) is a broad spectrum organophosphorus insecticide (OP) and extensively used for agricultural purpose (Kavitha and Rao 2009). In particular, the PFF is used as one of top priority pesticides in controlling the pests of cotton in China. The major associating problems with PFF are its toxic to other non-targeted species and its potential to contaminate ground water (Reddy and Rao 2008; Ismail et al. 2009). The environmental pollution from PFF is usually neglected because of its short half life (Tomlin 1994). However, Zhao et al. (2008) detected about $0.010 \mathrm{mg} / \mathrm{kg}$ PFF residue in an experimental cotton soils even after 60 days indicating the prolonged persistency of PFF. Because of yearly spraying, PFF may accumulate continuously in soils and pose a major ecological threat to the soil ecosystem. It has been suggested that even small quantities of PFF could lead to adverse effects on ecosystems because of its potent toxicity in environment (Reddy and Rao 2008). Therefore, it is necessary to evaluate the toxicity and risk of PFF to native soil organisms.

Many studies have assessed the toxicity of PFF to aquatic organisms, such as, rainbow fish, cladoceran, euryhyaline fish, and carp (Kumar and Chapman 1998; Woods et al. 2002; Kavitha and Rao 2009). However, studies on PFF toxicity to organisms residing in terrestrial ecosystem are few. It was reported that the 28 days- $\mathrm{LC}_{50}$ value of PFF to the earthworm, Aporrectodea caliginosa, was $127 \mathrm{mg} /$ $\mathrm{kg}$ based on a OECD artificial soil (Mosleh et al. 2003), whereas the $48 \mathrm{~h} \mathrm{LC}_{50}$ value to the earthworm, Eisenia foetida, was $3.55 \mu \mathrm{g} / \mathrm{cm}^{2}$ (which are equivalent to 101-222 mg/L) based on a filter paper method (Reddy and Rao 2008). These tests were not suitable for an early warning or for evaluating the risk of PFF contaminated 
soils, because the threshold concentrations based on them were over high for soil safe and the concentration levels could even hurt many other organisms.

Soil animals play critical role in soil decomposition and nutrient cycles and may be particularly responsive indicators for the assessment of soil quality (O'Neill et al. 2009). Some of invertebrates are ecologically relevant species for evaluation of chemical toxicity (Eom et al. 2007). The springtail, F. candida, is one of the most important soil invertebrates, and is used as a model organism to evaluate soil quality (Fountain and Hopkin 2005; Jager et al. 2007). Test endpoints, such as survival, growth, reproduction, and hsp70 gene expression have been widely used in toxicity assessments of contaminated soils because of their sensitive responses to environmental stress (Scott-Fordsmand et al. 2000; Fountain and Hopkin 2004; Fernandez et al. 2005; Dawson et al. 2007; Criel et al. 2008). However, the biological responses could be different at different organization levels of $F$. candida exposed to the same contaminated soil (Liu et al. 2010b). It has been suggested that the response at a molecular level was considered to be the most reliable and sensitive, which could be used as a biomarker for early diagnosis of contaminated soil (Timmermans et al. 2005; Nota et al. 2008)

Soil microorganisms should also be considered when assessing the ecological risk of pollutants in soil because of their importance in soil fertility and health (O'Halloran et al. 2005). Microbial functional responses, such as soil respiration and potential nitrifying activity, have been also used as toxicity endpoints for evaluation of soil quality in recent study (Smolders et al. 2001; Jager et al. 2007; Hund-Rinke and Simon 2008; Lors et al. 2011). In particular, nitrification has been considered to be not only an important process of nitrogen cycle but also one of the most sensitive responses to chemical stress (Mertens et al. 2006; Schauss et al. 2009; Liu et al. 2010a). Therefore, a comparative study focusing on the effects of on soil $F$. candida and ammonia-oxidizers would be useful in ecological risk assessment of PFF contaminated soil.

The objective of the present study was to identify a sensitive indicator for PFF ecotoxicity in soils by comparing the responses of $F$. candida and ammonia-oxidizers to PFF stress. The endpoints for $F$. candida (survival, reproduction, and hsp70 gene expression) and soil potential nitrification rate (PNR), abundance of ammonia-oxidizers were measured using a series of the toxicity tests. Two types of soil were selected as substrates to examine the effects of soil properties on the bioavailability of the pollutant. We hypothesized that the obtained toxicological data would be useful for risk assessment of PFF contaminated soil.

\section{Materials and methods}

Test soil and $F$. candida

For the present study two pristine soils, which were considered be little contaminated, were collected from a vegetable field in the suburbs of Beijing (BJ, $116^{\circ} 09^{\prime} \mathrm{E}$, $40^{\circ} 13^{\prime} \mathrm{N}$ ) and rice field in Taoyuan (TY, $111^{\circ} 27^{\prime} \mathrm{E}$, $28^{\circ} 55^{\prime} \mathrm{N}$ ) county of Hunan province, China. The BJ soil type was fluvo-aquic soil with $13 \%$ clay content. The $\mathrm{pH}$ value was 7.14 and the organic matter (OM) content was $2.05 \%$. The TY soil type was paddy soil ( $\mathrm{pH}$ value, 4.05$)$ with $40 \%$ clay content and $2.9 \%$ OM content.

The strain of $F$. candida was provided by the Institute of Plant Physiology and Ecology, Chinese Academy of Sciences (Shanghai, China). The individuals were cultured at $20 \pm 1{ }^{\circ} \mathrm{C}$ with a $12: 12 \mathrm{~h}$ light/dark cycle. The springtails were kept in Petri dishes containing a mixture of watersaturated charcoal and plaster-of-Paris (1:8) and fed with granulated baker's dry yeast. The humidity was maintained by quantify addition of water at an interval of 1 week.

\section{Tests of survival and reproduction of $F$. candida}

Acute toxicity tests of survival were conducted based on the results of pre-experiments. The soils were spiked with series of PFF concentrations, i.e., 0.05, 0.1, 0.2, $0.4,1$ and $2 \mathrm{mg} / \mathrm{kg}$ for the BJ soil and $0.5,1,2,4$ and $10 \mathrm{mg} / \mathrm{kg}$ for the TY soil to obtain the lowest lethal concentration in the TY soil, by adding a solution of PFF with acetone. Equal volumes of acetone were used for spiking, and it was applied to $10 \%$ of the soil. The spiked soils were left in a ventilation cabinet in order to let the acetone evaporate, avoiding its effect on test biology. Then the distilled water was added to the soil until the moisture level was 55\% water holding capacity. Ten adult springtails were introduced to each vessel containing $30 \mathrm{~g}$ of test soil. The vessels were kept at $20 \pm 1{ }^{\circ} \mathrm{C}$ with a $12: 12 \mathrm{~h}$ light/dark cycle of $48 \mathrm{~h}$. At the end of exposure, surviving adults were counted after extraction by floatation with water. All the tests consisted of five replicates for each concentration. Chronic toxicity tests of reproduction with $F$. candida were conducted following the ISO 11267 method for reproduction (1999). A series of polluted soils (i.e., $0.05,0.1,0.2$ and $0.4 \mathrm{mg} / \mathrm{kg}$ ) were made as above, and 10 springtails (10-12 days old) were exposed in each experimental vessel containing $30 \mathrm{~g}$ of tested soil for 4 weeks. The replicates and incubation conditions were the same as those in the survival tests. After exposure, juveniles were counted after extraction by floatation with water.

\section{Transcriptional responses of hsp70 in F. candida}

The hsp70 protein-coding gene can be induced to express at extremely low level of pollutant and it has been widely 
used as a biomarker for environmental monitoring. Based on results of the survival test, transcriptional responses of hsp70 in $F$. candida were conducted on the series of PFF concentration, i.e., $0.05,0.1,0.20 .3$ and $0.4 \mathrm{mg} / \mathrm{kg}$ for the two soils. There were four replicates for both control and spiked soils. Thirty adult springtails were placed into each test vessel (5 cm in diameter and $7 \mathrm{~cm}$ in depth) containing $30 \mathrm{~g}$ of test soil. Other general conditions during the exposure were the same as those in the reproduction assay. When the $48 \mathrm{~h}$ exposure was ended, the springtails were extracted from the experimental soil, and moved into Petri dishes containing a mixture of charcoal and plaster-of-Paris to remove surplus water. Then they were put into sterile tubes in which they were snap frozen in liquid nitrogen and then stored at $-80^{\circ} \mathrm{C}$ for RNA extraction. Additionally, time-transcription tests of hsp70 were conducted as the same exposure procedure as above. The soils were spiked with a final concentration of $0.1 \mathrm{mg} / \mathrm{kg}$ soil PFF. Following exposure, springtails were collected after different exposure times, i.e., 6, 12, 24, 48, 96 and $144 \mathrm{~h}$.

Hsp70 gene expression analyses were conducted on total RNA from the exposed springtails, using Trizol reagent (Molecular Research Center, Inc. Invitrogen, USA) according to manufacturer' instructions. The first strand cDNA was synthesized using reverse transcriptase MMLV (Promega) and oligod(T $)_{15}$ according to the manufacturer's instructions. The $\beta$-actin gene was chosen as an internal control for hsp70 gene quantification (Timmermans et al. 2007). The two genes were quantified by SYBR Green I assays using the primer set ACT1-F (GCGACGTTGAT ATCCGAAAG) and ACT1-R (AGGCAGTGATTTCCTT TTGC) for $\beta$-actin gene, and the primer set H7-1F (GG ACTTTGACAACCGAATGG) and H7-1R (CCACGGA AAAGATCAGCATT) for hsp70 gene. Real-time PCRs (qPCR) for each target gene was conducted according to the study by Liu et al. (2010b). For each mRNA, the absence of contamination (genomic DNA) was checked using a no-RT control with $\beta$-actin gene and hsp70 primer. Ten-fold serial dilutions of a known copy number of plasmid DNA were subjected to real-time PCR assay in triplicates to generate standard curves for quantifying the two interesting genes.

\section{Potential nitrification activity}

Tested soils were made as above with various concentrations of PFF $(0,0.25,0.5,1,2,4$ and $10 \mathrm{mg} / \mathrm{kg})$. PNR was measured at weeks 1, 2 and 4 using the chlorate inhibition method (Kurola et al. 2005). Briefly, $5.0 \mathrm{~g}$ of fresh soil was added to a $50 \mathrm{ml}$ centrifuge tube containing $20 \mathrm{ml}$ of phosphate buffer solution (PBS) (g/l: NaCl, 8.0; $\mathrm{KCl}, 0.2$; $\left.\mathrm{Na}_{2} \mathrm{HPO}_{4}, \quad 0.2 ; \mathrm{NaH}_{2} \mathrm{PO}_{4}, 0.2 ; \mathrm{pH} 7.4\right)$ with $1 \mathrm{mM}$ $\left(\mathrm{NH}_{4}\right)_{2} \mathrm{SO}_{4}$. Potassium chlorate with a final concentration of $10 \mathrm{mM}$ was added to inhibit nitrite oxidation. After $24 \mathrm{~h}$ incubation of the suspension in a dark incubator at $25^{\circ} \mathrm{C}$, samples were subjected to $\mathrm{NO}_{2^{-}} \mathrm{N}$ extraction and $5 \mathrm{ml}$ of $2 \mathrm{M} \mathrm{KCl}$ was added to the tubes. Finally, the $\mathrm{NO}_{2^{-}}-\mathrm{N}$ in extraction was determined spectro-photometrically at $540 \mathrm{~nm}$ with $N$-(1-naphthyl) ethylenediamine dihydrochloride.

\section{Quantification of amoA genes by real-time PCR assays}

Soil DNA was extracted from $0.5 \mathrm{~g}$ fresh soil samples using Ultra-clean ${ }^{\mathrm{TM}}$ soil DNA Isolation Kits (MoBio Laboratory, USA) according to the manufacturer's protocol. The abundances of ammonia-oxidizing bacteria (AOB) and ammonia-oxidizing archaea (AOA) in the spiked soils were determined after exposing for 4 weeks, basing on the functional amo $A$ gene. The $25 \mu$ reaction mixture included $12.5 \mu$ l Premix Ex Taq ${ }^{\mathrm{TM}}$ (Takara Biotechnology, Japan), $1 \mu \mathrm{l}$ of BSA, $0.5 \mu \mathrm{l}$ of each primer $(10 \mu \mathrm{M})$ and $2 \mu \mathrm{l}$ of 10-fold diluted extracted DNA as template. Bacterial amoA gene was quantified using the primers amoA1F and amoA2R (Rotthauwe et al. 1997), and the primers for archaeal amoA gene were arch-amoAF and Arch-amoAR (Francis et al. 2005).

\section{Statistical analyses}

The ECx values were calculated using the statistical package SigmaPlot 10.0. These values and their $95 \%$ confidence intervals were calculated from logistic regression models (Vanewijk and Hoekstra, 1993). No-observedeffect concentrations (NOEC) and low-observed-effect concentrations (LOEC) were determined by comparing survival, reproduction rate and the hsp70 gene expression level, and PNRs with corresponding control using MannWhitney $U$ tests. Statistical significance was considered to be at $P<0.05$. Relative gene expression was calculated by quantification of the hsp70 gene compared to quantification of the $\beta$-actin gene and the control treatment was normalized as a value of 1 . One-way analysis of variance (ANOVA) was used to assess differences between treatments, and all results are represented as means with standard errors. Statistical significance was assessed by the software SPSS 13.0.

\section{Results}

Survival of $F$. candida

The effects of PFF on the survival (48 h) of the F. candida in the BJ and TY soils are investigated (Fig. 1). Significantly adverse effects on the survival of the $F$. candida 


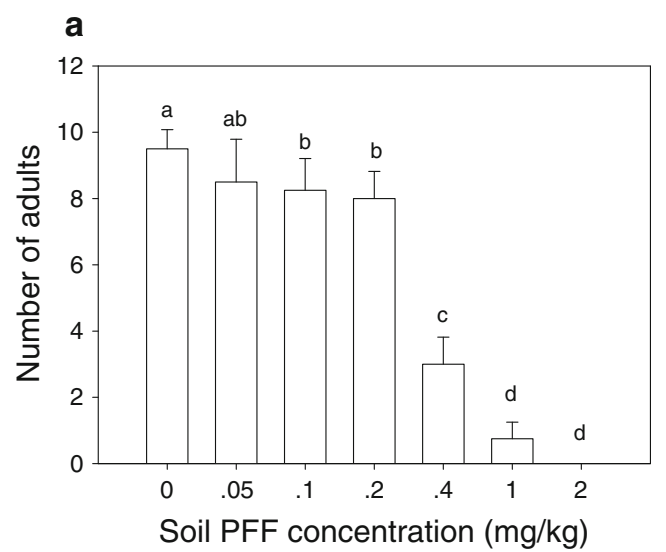

Fig. 1 Survival tests of the springtail $F$. candida exposed to the PFFcontaminated soils for 2 days. Mean values are given per replicate \pm standard deviation for four replicates. Columns within each b

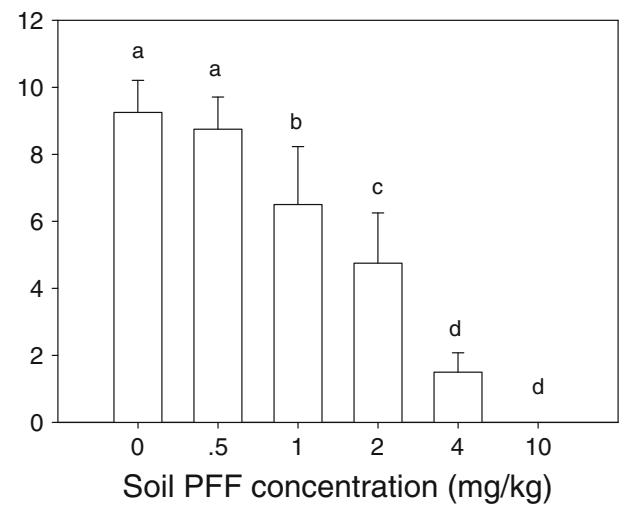

concentration not sharing the same letter are significantly different $(P<0.05)$. a Beijing soil; b Taoyuan soil
Table 1 No-observed-effect concentration (NOEC), lowestobserved-effect concentration (LOEC), effect concentration with $10 \%$ effect $\left(\mathrm{EC}_{10}\right)$, and an effect concentration with $50 \%$ effect $\left(\mathrm{EC}_{50}\right)$ per $\mathrm{mg} \mathrm{PFF} / \mathrm{kg}$ soil for $F$. candida after exposure to two types of soils

${ }^{\text {a }}$ Soil collected from Beijing

b Soil collected from Taoyuan

\begin{tabular}{lllll}
\hline & NOEC & LOEC & $\mathrm{LC}_{10} / \mathrm{EC}_{10}$ & $\mathrm{LC}_{50} / \mathrm{EC}_{50}$ \\
\hline $\begin{array}{l}\text { Adult survival } \\
\mathrm{BJ}^{\mathrm{a}} \text { soil }\end{array}$ & 0.05 & 0.1 & & \\
TY & & 0.11 & 0.34 \\
Reproduction & 0.5 & 1 & 0.52 & \\
BJ soil & & & & 0.10 \\
TY soil & $<0.05$ & 0.05 & 0.04 & 0.09 \\
Hsp70 & $<0.05$ & 0.05 & 0.04 & 0.24 \\
BJ soil & & & & $>0.4$ \\
TY soil & 0.2 & 0.3 & - & \\
PNR & 0.3 & 0.4 & & 0.27 \\
BJ soil & & & 0.13 & 0.72 \\
TY soil & $<0.25$ & 0.25 & 0.72 & \\
\hline
\end{tabular}

were observed in the two soils, and the mortality increased with ascending PFF concentration. However, the different sensitivity of survival $F$. candida to the chemical was found between the two soils. The $\mathrm{LC}_{50}$ values were 0.34 and $2.03 \mathrm{mg} / \mathrm{kg}$ for the BJ and the TY soils, respectively (Table 1). The lowest-observed-effect concentration (LOEC) was $0.1 \mathrm{mg} / \mathrm{kg}$ in the BJ soil while $1 \mathrm{mg} / \mathrm{kg}$ in the TY soil. Additionally, there was no survival at the highest exposed concentration of $2 \mathrm{mg} / \mathrm{kg}$ in the BJ soil or $10 \mathrm{mg} /$ $\mathrm{kg}$ in the TY soil. Hence PFF was more toxic in the BJ soil compared to that in the TY soil.

\section{Reproduction of $F$. candida}

Over $80 \%$ survival rate and more than 100 juveniles produced in the control treatment showed that the reproduction tests were valid. The numbers of juveniles decreased significantly with increasing PFF dosages in the both spiked soils (Fig. 2). Both of the LOEC values found at were the lowest spiked concentration of $0.05 \mathrm{mg} / \mathrm{kg}$. No juvenile survived at $0.4 \mathrm{mg} / \mathrm{kg}$ PFF. However, there were different responses of $F$. candida reproduction in the two tested soils. Relatively fewer juveniles existed in the control treatment of the BJ soil than those in the control treatment of the TY soil. The 28 days $\mathrm{EC}_{50}$ value based on the reproduction was calculated to be $0.10 \mathrm{mg} / \mathrm{kg}$ for the $\mathrm{BJ}$ soil and $0.09 \mathrm{mg} / \mathrm{kg}$ for the TY soil, respectively (Table 1).

Transcriptional responses of the hsp70 gene in $F$. candida

The effect of PFF on the hsp70 gene expression of $F$. candida is shown in Fig. 3. An increase in hsp70 gene expression was observed with the increasing PFF level in the BJ soil: a dose-response relationship $\left(\mathrm{EC}_{50}: 0.24 \mathrm{mg} /\right.$ $\mathrm{kg}$ ). In the TY soil, however, the $\mathrm{EC}_{50}$ value, based on the hsp70 gene expression, was above $0.4 \mathrm{mg} / \mathrm{kg}$. Significantly higher expression of the hsp70 gene was found in the BJ 


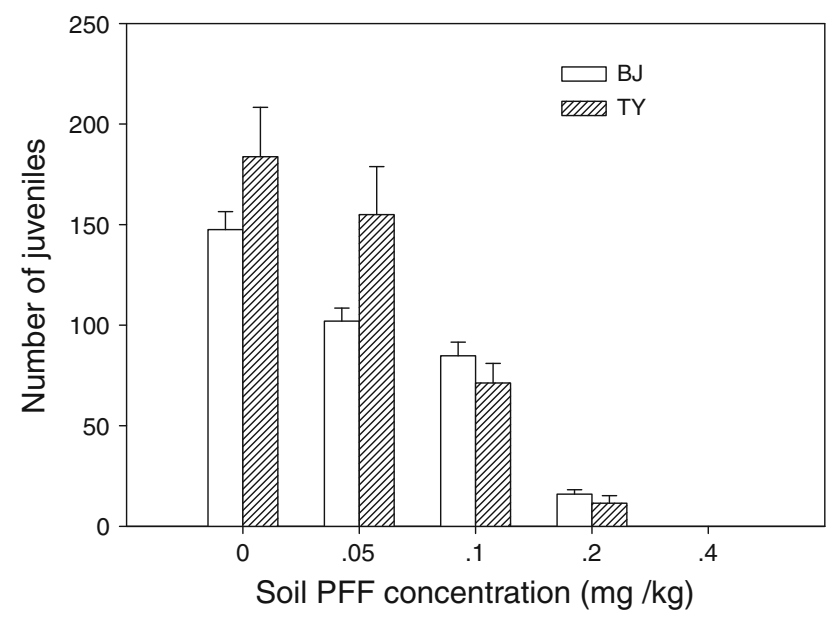

Fig. 2 Reproduction test of $F$. candida exposed to the PFF-contaminated soils for 28 days. Mean values are given per replicate \pm standard deviation for four replicates. Columns within each concentration not sharing the same letter are significantly different $(P<0.05)$

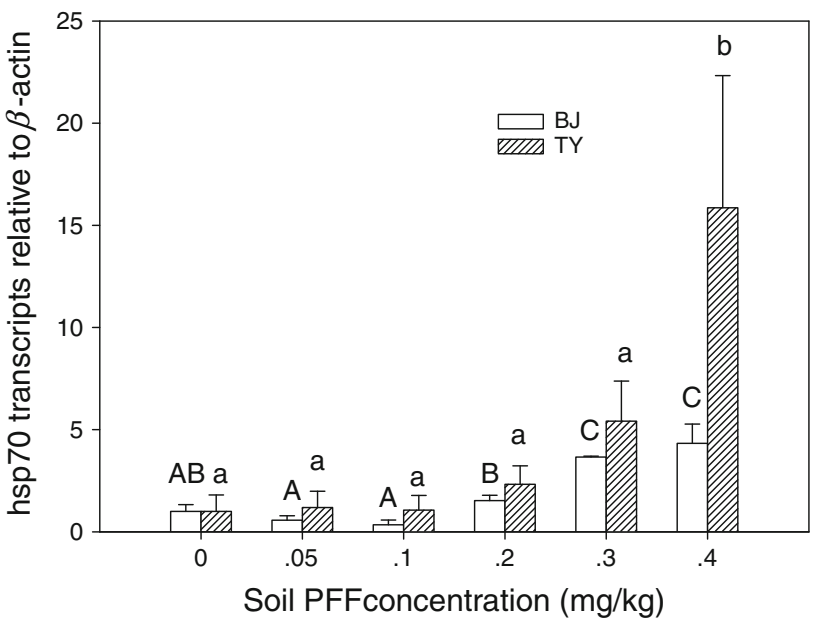

Fig. 3 Expression of hsp70 gene in $F$. candida exposed to a control and increasing test concentrations of soil PFF. Bars are the mean of 4 expression relative $\pm \mathrm{SE}$. Columns within each concentration not sharing the same letter are significantly different $(P<0.05)$

soil when the PFF concentration was equal to or above $0.30 \mathrm{mg} / \mathrm{kg}(P<0.05)$, whilst there was no significant expression variation of hsp70 gene at this concentration in the TY soil. The highest expression levels of the hsp70 gene in the two soils were observed at $0.4 \mathrm{mg} \mathrm{PFF} / \mathrm{kg}$.

Time-response relationships were also investigated in the two soils. No significant difference was observed in the expression of the hsp70 gene between 0 and $24 \mathrm{~h}$ in the BJ contaminated soil (Fig. 4). Afterwards the hsp70 gene expression increased significantly about 2-fold. Subsequently there was some fluctuation in the expression levels, which remained higher than the expression of the gene in the control springtail. For the TY soil, the hsp70 expression

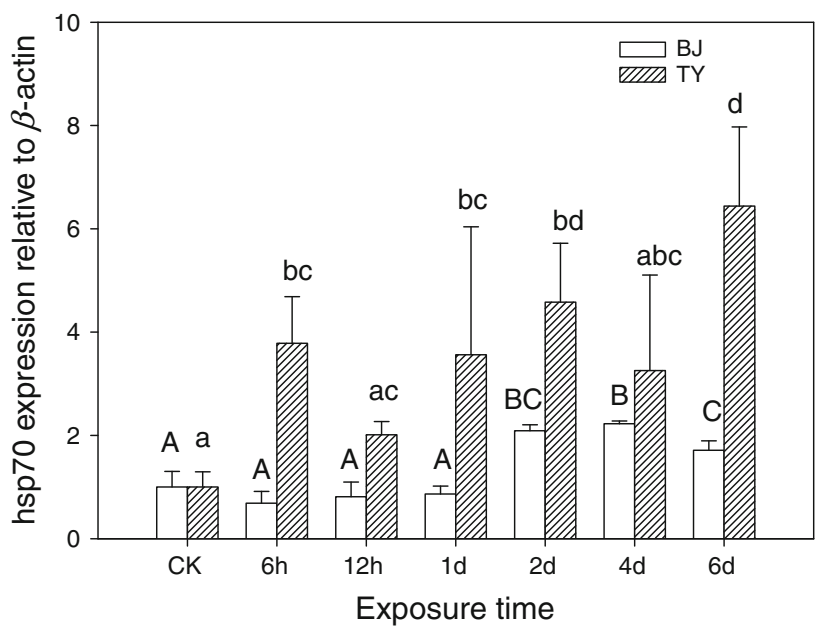

Fig. 4 Expression of hsp70 gene in $F$. candida at different exposure times at a concentration of $1 \mathrm{mg} / \mathrm{kg}$ PFF in soil. Bars are the mean of four expression relative \pm SE. Columns within each time not sharing the same letter are significantly different $(P<0.05)$

in all of the treatments was significantly higher compared with that in the control treatment, except the $12 \mathrm{~h}$ and 4 days treatments.

\section{Nitrification activity}

The PNRs in the two soils were measured at week 1,2 and 4 after the addition of PFF (Fig. 5). All the PNR values in the two spiked soils were significantly lower than those in the control treatments in their respective incubation periods. In the BJ soil, there was a decreasing trend of PNRs with ascending soil PFF concentrations, and the PNRs in each incubation period tend to increase with extending exposure time. The PNR curve correlated with the PFF concentration at week 1 and they fitted well with logistic dose-response model $(P<0.05)$, from which the $\mathrm{EC}_{50}$ value was calculated as $0.27 \mathrm{mg} / \mathrm{kg}$. However, the average PNR value in the TY soil was much higher compared with that of BJ soil. The PNRs at week 1 in the TY soil were higher than the values measured at week 2 and 4 , whereas no consistent variation trend of PNR was found.

\section{Abundance of ammonia-oxidizers}

The abundance of ammonia-oxidizers in the soils was determined after 4 weeks of incubation. There was no consistent variation trend in the bacterial or archaeal amoA gene copy numbers along the elevating soil PFF concentrations in the two soils (Fig. 6). No significant difference was found between the average bacterial and archaeal amoA gene copy number in the BJ soil. However, archaeal amoA gene copy number was much higher than that of bacteria in the TY soil. 
Fig. 5 The PNRs ( \pm standard error) of soil samples related to the total amount of added PFF at different incubation periods $(n=3)$. a Beijing soil; b Taoyuan soil
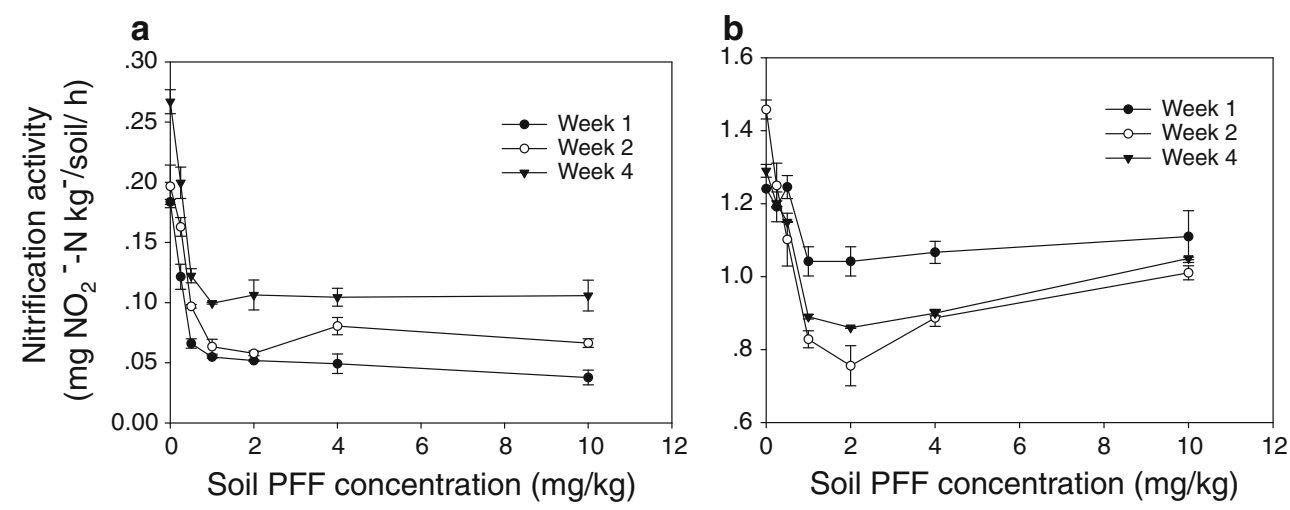
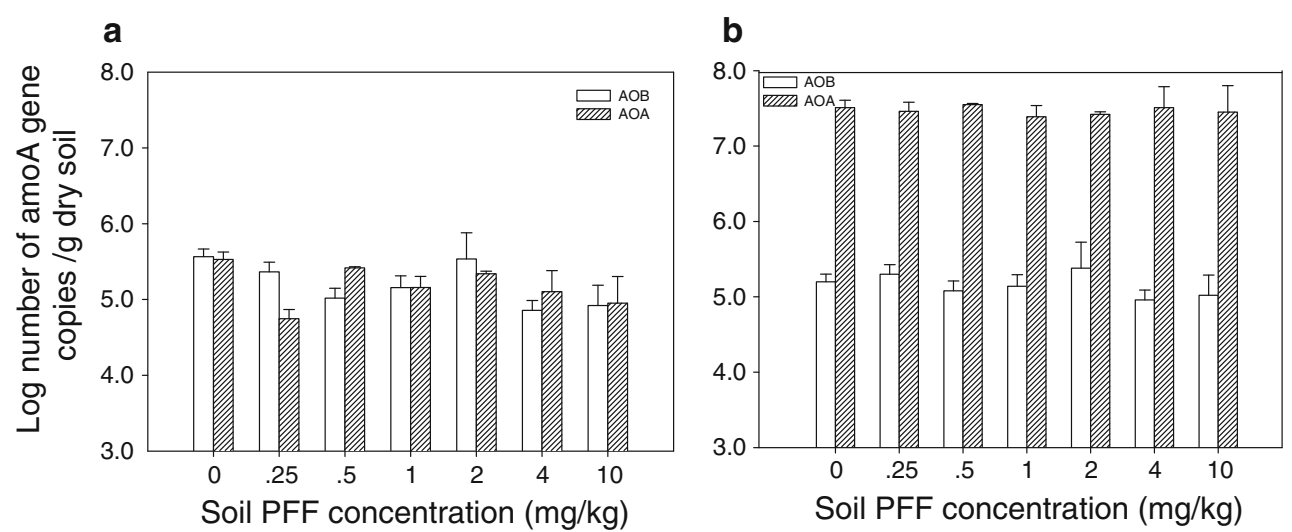

Fig. 6 Quantification of bacterial and archaeal amoA genes in the soils with different PFF concentrations. Error bars represent standard errors. a Beijing soil; b Taoyuan soil

\section{Discussion}

Responses of $F$. candida to the soil PFF stress

The present study compared the different responses of F. candida to soil PFF stress through the acute toxicity tests of survival and hsp70 gene expression, and the chronic toxicity test of reproduction. Experimental results demonstrated that the impregnated PFF impacted the survival and reproduction, which were found to be very sensitive to the PFF stress. The rates of survival and reproduction and the soil PFF concentrations accorded with a logistic doseresponse relationship. Additionally, the $\mathrm{LC}_{50}$ value based on the survival test was more than three-fold of the $\mathrm{EC}_{50}$ value based on the reproduction test in the $\mathrm{BJ}$ soil, while the $\mathrm{LC}_{50}$ value was 20 -fold of the $\mathrm{EC}_{50}$ value in the $\mathrm{TY}$ soil. These different responses could be attributed to the different bioavailability of PFF which depended on the soil property. Anyhow the reproduction and survival of $F$. candida were both sensitive indicators for monitoring of soil pollution by PFF. In particular, the survival test should be a suitable diagnosis endpoint for its fast tracking of PFF toxicity.
It has been suggested that measurement at molecular level biological responses could be useful in early environmental monitoring and risk assessment (Nota et al. 2008; Roelofs et al. 2008; van Straalen and Roelofs 2008), since the variation of gene expression had been produced before the variation of higher organization level could be observed (Spurgeon et al. 2004). In the present study, however, the sensitivity of hsp70 gene expression in $F$. candida was comparable to the responses at individual level in the both BJ and TY soils. This finding suggested that the response at molecular level of $F$. candida to the OP insecticides PFF could be not so sensitive as its response to the heavy metal $\mathrm{Hg}$ by the previous study (Liu et al. 2010b). The result of time-response described above was similar with the previous study revealing that the hsp70 gene expression level was significantly higher after $48 \mathrm{~h}$ exposure, further demonstrating that the hsp70 protein coding was strongly induced in a short time. Nevertheless, the hsp70 gene expression was relatively stable after the $48 \mathrm{~h}$ exposure in the BJ soil. The enough hsp70 protein could have produce for self-protection and exhibited resistance to the stress after the $48 \mathrm{~h}$ exposure, which supported the previous argument that the up-regulation of 
some genes was involved in the tolerance to prolonged exposure to stressors (Morgan et al. 2007). However, it is difficult to understand the intricate variation of the hsp70 gene expression in the TY soil.

\section{Response of ammonia-oxidizers to soil PFF stress}

Oxidization of ammonia is a key process in the global nitrogen cycle resulting in the formation of nitrate (Schauss et al. 2009). However, the activity and abundance of ammonia-oxidizers could be impacted by exogenous pollutant in soils. The results described above indicated that the added PFF had significant effect on the potential nitrifying activity, with a reduction of PNRs with the elevating soil PFF concentration. The LOEC values in the two soils were the lowest spiked concentration of $0.25 \mathrm{mg} / \mathrm{kg}$ at all the exposure times, which demonstrated that the PNR was very sensitive to the PFF stress. In the BJ soils, the PNRs determined at week 1 and the PFF concentrations fitted well with dose-response relationship, which could predict or evaluate the toxic effect of PFF on soil nitrification. The increasing PNRs with the extending exposure time were observed in the BJ soils, and this agreed to the previous study suggesting that activity of ammonia-oxidizers had a resilience trend in the contaminated soil (Liu et al. 2010a). In contrast, the PNRs in the TY soil did not exhibited the similar resilience trend of nitrifying activity with the extending expose time. Relatively the mean PNR value determined at week 1 was higher than those were determined at weeks 2 and 3, suggesting that the added PFF could exert most toxic effect on activity of ammonia-oxidizers in a short time but the increased incubation time did not weaken the adverse effect.

The results of quantification of $a m o A$ gene indicated that the added PFF did not significantly impact on the abundance of ammonia-oxidizers in the two soils, which was supportive to the previous study suggesting that the added pollutants could not did not change the abundance of the soil ammoniaoxidizers (Stephen et al. 1999; Frey et al. 2008; Liu et al. 2010a). Therefore, the total abundance of ammonia-oxidizers could not indicate the effects of pollutants to soil nitrifying activity. Probably it is that some of clusters in ammonia-oxidizer community were sensitive to some environmental stress, for example, it was found the percentage of cluster 3a.1 in AOB community appeared to a consistent trend of decreasing with ascending soil $\mathrm{Hg}$ stress (Liu et al. 2010a). However, no change of total amoA gene copy number was found in the soils, which could be attributed to the increase of quantity of other resistant groups.

Effects of soil properties on the toxicity tests of PFF

Soil properties have a great of effects on the bioavailability and toxicity of pollutants (Smit and van Gestel 1998; Lock and Janssen 2001; Bradham et al. 2006; van Gestel et al. 2011). Similarly in the present study, it was observed that the soil properties distinctly impacted the survival, reproduction, hsp70 gene expression of the $F$. candida and the soil potential nitrification activity under the PFF stress. Relatively both $\mathrm{LOEC}$ and $\mathrm{LC}_{50}$ values in the $\mathrm{BJ}$ soil were lower than those in the TY soil. The higher $\mathrm{EC}_{50}$ value based on the PNR tests in the TY soil further demonstrated its relatively low toxicity. This could be explained by soil indigenous characteristics. The TY soil had relatively high $\mathrm{OM}$ and clay content, which could adsorb and fix the PFF to soil particles, resulting in the reduction of its bioavailability to the soil organism. This was agreement to most of previous results suggesting that high content of OM and clay mineral could decrease the toxicity of pollutants in soils (Weng et al. 2004; Usman et al. 2005). In addition, the soil properties had obviously influenced the response of hsp70 gene expression in $F$. candida in the two soils. Consequently, the relationship between hsp70 expression levels and PFF concentrations could be fitted to a logistic dose-response curve in the BJ soil, whereas the relationship of them was disordered in the TY soil.

\section{Conclusion}

The present study first examined the responses of soil functional animal and microorganisms to the stress by OP insecticide PFF. The study of comparison among the different endpoints revealed that the reproduction of $F$. candida appeared to be the most sensitive endpoint of toxicity diagnosis, however, it was not considered to be a promising method for evaluating the toxicity of PFF in soil because the test was more time-consuming. Considering the easy and fast procedure, the survival of $F$. candida should be a more suitable diagnosis endpoint for screening the toxicity of PFF in soil in a short time. The hsp70 gene expression could be also used as an important toxicity parameter for monitoring or evaluate PFF pollution despite of its relatively complicated procedure, and further study needs to be carried to understand its responsive mechanism. Additionally, the soil potential nitrification, as an endpoint, can provide optional means of quantifying environmental harm where the ammonia-oxidizer is critically concerned. We recommend this endpoint could be used as a comparative parameter along with endpoints of $F$. candida for evaluating the toxicity of contaminated soil. However, soil properties should be considered carefully prior to the performance of soil toxicity assessment.

Acknowledgments This study was supported by the National High Technology Research Program (2009AA06Z402), the Ministry of environmental protection (201006032-03) and the Natural Science 
Foundation of China (50921064). We would like to thank Dr. Luan Yunxia for providing the $F$. candida strain.

\section{References}

Bradham KD, Dayton EA, Basta NT, Schroder J, Payton M, Lanno RP (2006) Effects of soil properties on lead bioavailability and toxicity to earthworms. Environ Toxicol Chem 25:769-775

Criel P, Lock K, Van Eeckhout H, Oorts K, Smolders E, Janssen CR (2008) Influence of soil properties on copper toxicity for two soil invertebrates. Environ Toxicol Chem 27:1748-1755

Dawson JJC, Godsiffe EJ, Thompson IP, Ralebitso-Senior TK, Killham KS, Paton GI (2007) Application of biological indicators to assess recovery of hydrocarbon impacted soils. Soil Biol Biochem 39:164-177

Eom IC, Rast C, Veber AM, Vasseur P (2007) Ecotoxicity of a polycyclic aromatic hydrocarbon (PAH)-contaminated soil. Ecotoxicol Environ Saf 67:190-205

Fernandez MD, Cagigal E, Vega MM, Urzelai A, Babin M, Pro J, Tarazona JV (2005) Ecological risk assessment of contaminated soils through direct toxicity assessment. Ecotoxicol Environ Saf 62:174-184

Fountain MT, Hopkin SP (2004) Biodiversity of Collembola in urban soils and the use of Folsomia candida to assess soil 'quality'. Ecotoxicology 13:555-572

Fountain MT, Hopkin SP (2005) Folsomia candida (Collembola): a "standard" soil arthropod. Annu Rev Entomol 50:201-222

Francis CA, Roberts KJ, Beman JM, Santoro AE, Oakley BB (2005) Ubiquity and diversity of ammonia-oxidizing archaea in water columns and sediments of the ocean. Proc Natl Acad Sci 102:14683-14688

Frey B, Pesaro M, Rudt A, Widmer F (2008) Resilience of the rhizosphere pseudomonas and ammonia-oxidizing bacterial populations during phytoextraction of heavy metal polluted soil with poplar. Environ Microbiol 10:1433-1449

Hund-Rinke K, Simon M (2008) Bioavailability assessment of contaminants in soils via respiration and nitrification tests. Environ Pollut 153:468-475

Ismail M, Ali R, Ali T, Waheed U, Khan QM (2009) Evaluation of the acute toxicity of profenofos and its effects on the behavioral pattern of fingerling common carp (Cyprinus carpio L., 1758). Bull Environ Contam Toxicol 82:569-573

ISO Soil quality-inhibition of reproduction of Collembola (Foslomia candida) by soil pollutants. No. 11267; ISO: Geneva, 1999

Jager T, Crommentuijn T, van Gestel CAM, Kooijman SALM (2007) Chronic exposure to chlorpyrifos reveals two modes of action in the springtail Folsomia candida. Environ Pollut 145:452-458

Kavitha P, Rao JV (2009) Sub-lethal effects of profenofos on tissuespecific antioxidative responses in a Euryhyaline fish, Oreochromis mossambicus. Ecotoxicol Environ Saf 72:1727-1733

Kumar A, Chapman JC (1998) Profenofos toxicity to the eastern rainbow fish (Melanotaenia duboulayi). Environ Toxicol Chem 17:1799-1806

Kurola J, Salkinoja-Salonen M, Aarnio T, Hultman J, Romantschuk M (2005) Activity, diversity and population size of ammoniaoxidising bacteria in oil-contaminated land farming soil. FEMS Microbiol Lett 250:33-38

Liu YR, Zheng YM, Shen JP, Zhang LM, He JZ (2010a) Effects of mercury on the activity and community composition of soil ammonia oxidizers. Environ Sci Pollut Res 17:1237-1244

Liu YR, Zheng YM, Zhang LM, Luan YX, He JZ (2010b) Effects of mercury on reproduction, avoidance, and heat shock protein gene expression of the soil springtail Folsomia candida. Environm Toxicol Chem 29:654-659
Lock K, Janssen CR (2001) Cadmium toxicity for terrestrial invertebrates: taking soil parameters affecting bioavailability into account. Ecotoxicology 10:315-322

Lors C, Ponge JF, Aldaya MM, Damidot D (2011) Comparison of solid-phase bioassays and ecoscores to evaluate the toxicity of contaminated soils. Environ Pollut 158:2640-2647

Mertens J, Springael D, De Troyer I, Cheyns K, Wattiau P, Smolders E (2006) Long-term exposure to elevated zinc concentrations induced structural changes and zinc tolerance of the nitrifying community in soil. Environ Microbiol 8:2170-2178

Morgan AJ, Kille P, Sturzenbaum SR (2007) Microevolution and ecotoxicology of metals in invertebrates. Environ Sci Technol 41:1085-1096

Mosleh YY, Ismail SMM, Ahmed MT, Ahmed YM (2003) Comparative toxicity and biochemical responses of certain pesticides to the mature earthworm Aporrectodea caliginosa under laboratory conditions. Environ Toxicol 18:338-346

Nota B, Timmermans MJTN, Franken O, Montagne-Wajer K, Mariën J, Boer MEd et al (2008) Gene expression analysis of Collembola in cadmium containing soil. Environ Sci Technol 42:8152-8157

O'Halloran K, Jones D, Booth L, Fisher P (2005) Ecotoxicity of sodium Fluoroacetate (compound 1080) to soil organisms. Environ Toxicol Chem 24:1211-1218

O'Neill KP, Godwin HW, Jimenez-Esquilin AE, Battigelli JP (2009) Reducing the dimensionality of soil micro invertebrate community datasets using indicator species analysis: implications for ecosystem monitoring and soil management. Soil Biol Biochem 42:145-154

Reddy NC, Rao JV (2008) Biological response of earthworm, Eisenia foetida (Savigny) to an organophosphorous pesticide, profenofos. Ecotoxicol Environ Saf 71:574-582

Roelofs D, Aarts MGM, Schat H, van Straalen NM (2008) Functional ecological genomics to demonstrate general and specific responses to abiotic stress. Funct Ecol 22:8-18

Rotthauwe JH, Witzel KP, Liesack W (1997) The ammonia monooxygenase structural gene amoA as a functional marker: molecular fine-scale analysis of natural ammonia-oxidizing populations. Appl Environ Microbiol 63(12):4704-4712

Schauss K, Focks A, Leininger S, Kotzerke A, Heuer H, Thiele-Bruhn $S$ et al (2009) Dynamics and functional relevance of ammoniaoxidizing archaea in two agricultural soils. Environ Microbiol 11:446-456

Scott-Fordsmand JJ, Krogh PH, Weeks JM (2000) Responses of Folsomia candida (collembolan: Isotomidae) to copper under different soil copper concentration histories in relation to risk assessment. Environ Toxicol Chem 19:1297-1303

Smit CE, Van Gestel CAM (1998) Effects of soil type, prepercolation, and ageing on bioaccumulation and toxicity of zinc for the springtail Folsomia candida. Environ Toxicol Chem 17:1132-1141

Smolders E, Brans K, Coppens F, Merckx R (2001) Potential nitrification rate as a tool for screening toxicity in metalcontaminated soils. Environ Toxicol Chem 20:2469-2474

Spurgeon DJ, Sturzenbaum SR, Svendsen C, Hankard PK, Morgan AJ, Weeks JM, Kille P (2004) Toxicological, cellular and gene expression responses in earthworms exposed to copper and cadmium. Comp Biochem Phys C 138:11-21

Stephen JR, Chang YJ, Macnaughton SJ, Kowalchuk GA, Leung KT, Flemming CA, White DC (1999) Effect of toxic metals on indigenous soil p-subgroup proteobacterium ammonia oxidizer community structure and protection against toxicity by inoculated metal-resistant bacteria. Appl Environ Microbiol 65:95-101

Timmermans M, Ellers J, Roelofs D, Van Straalen NM (2005) Metallothionein mRNA expression and cadmium tolerance in 
metal-stressed and reference populations of the springtail Orchesella cincta. Ecotoxicology 14:727-739

Timmermans MJ, de Boer ME, Nota B, de Boer TE, Marien J, KleinLankhorst RM et al (2007) Collembase: a repository for springtail genomics and soil quality assessment. BMC Genomics 8:341

Tomlin CDS (1994) The pesticide manual, incorporating the agrochemicals handbook, 10th edn. The Royal Society of Chemistry and British Crop Protection Council, Cambridge

Usman A, Kuzyakov Y, Stahr K (2005) Effect of clay minerals on immobilization of heavy metals and microbial activity in a sewage sludge-contaminated soil. J Soils Sediment 5:245-252

van Gestel CAM, Borgman E, Verweij RA, Ortiz MD (2011) The influence of soil properties on the toxicity of molybdenum to three species of soil invertebrates. Ecotoxicol Environ Saf 74(1):1-9 van Straalen NM, Roelofs D (2008) Genomics technology for assessing soil pollution. J Biol 7:19

Vanewijk PH, Hoekstra JA (1993) Calculation of the EC50 and its confidence interval when subtoxic stimulus is present. Ecotoxicol Environ Saf 25:25-32

Weng LP, Wolthoorn A, Lexmond TM, Temminghoff EJM, Van Riemsdijk WH (2004) Understanding the effects of soil characteristics on phytotoxicity and bioavailability of nickel using speciation models. Environ Sci Technol 38:156-162

Woods M, Kumar A, Correll R (2002) Acute toxicity of mixtures of chlorpyrifos, profenofos, and endosulfan to Ceriodaphnia dubia. B Environ Contam Tox 68:801-808

Zhao WY, Shen CL, Ding N, Jia SM, Fan ZX (2008) Residual analysis of profenofos in cotton and soil. J Qingdao Univ Sci Technol 29:305-330 